\title{
PENGEMBANGAN MODUL FISIKA BERORIENTASI INQUIRY UNTUK PESERTA DIDIK
}

\author{
Vira Novia Riska1, Rahmi Zulva ${ }^{1 *}$ dan Silvi Trisna ${ }^{1}$ \\ ${ }^{1}$ Pendidikan Fisika, STKIP PGRI Sumatera Barat, Kota Padang, Indonesia \\ ${ }^{*}$ E-mail : $\underline{\text { rahmi.zulva@gmail.com }}$
}

\begin{abstract}
ABSTRAK
Tujuan penelitian ini adalah untuk menciptakan modul fisika berorientasi inquiry yang valid dan praktis karena kurangnya bahan ajar yang menarik. Penelitian ini merupakan penelitian pengembangan yang berorientasi inquiry. Jenis penelitian yang digunakan dalam penelitian ini adalah Research and Development (R\&D). Subjek dalam penelitian ini adalah pendidik dan peserta didik sebanyak 28 orang. Prosedur penelitian yang digunakan dalam penelitian ini adalah model 4-D yaitu define (pendefenisian) design (perancangan), develop (pengembangan), dan disseminate (penyebaran). Instrumen yang digunakan dalam penelitian ini adalah lembar validasi produk dan lembar praktikalitas produk. Berdasarkan hasil validasi diperoleh bahwa modul memiliki kategori sangat valid dengan persentase 83,91\% dan memiliki kategori sangat praktis dengan persentase 92,65\%. Modul dapat digunakan dalam proses pembelajaran di kelas untuk membantu pemahaman peserta didik.
\end{abstract}

Kata kunci: Modul, Validasi, Praktikalitas

\begin{abstract}
The purpose of this study was to create a physics module oriented to the inquiry learning model that is valid and practical due to the lack of attractive teaching materials. This research is a research and development using the inquiry model. The type of research used in this research is Research and Development (R\&D). The subjects in this study were 28 educators and students. The research procedure used in this study is a 4-D model, namely define design, develop, and disseminate. The instruments used in this study were the product validation sheet and the product practicality sheet. Based on the validation results, it is found that the module has a very valid category with a percentage of $83.91 \%$ and a very practical category with a percentage of $92.65 \%$. Modules can be used in the learning process in the classroom to help students understand.
\end{abstract}

Keywords: Module, Validity Practicality,

DOI: http://dx.doi.org/10.15575/jotalp.v6i1.10620

Received: 18 Desember 2020 ; Accepted: 11 Februari 2021 ; Published: 28 Februari 2021 


\section{PENDAHULUAN}

Pendidikan adalah hal yang penting untuk mempersiapkan diri seseorang dalam menghadapi masa yang akan datang, melalui pendidikan seseorang mampu mendapat wawasan, pengetahuan, kemampuan, keterampilan, nilai serta sikap yang sangat berguna bagi kehidupan bangsa serta negara Pendidikan merupakan usaha sadar serta terencana dalam mewujudkan suasana belajar, aktivitas belajar supaya peserta didik aktif dalam mengembangkan potensi dirinya agar memiliki kekuatan spiritual keagamaan, pengendalian diri, kepribadian, kecerdasan, akhlak mulia, serta keterampilan yang diperlukan dirinya, masyarakat, bangsa serta negara (UU No 20 Tahun 2003). Berdasarkan pernyataan yang diuraikan, maka untuk mencapai semua itu diperlukan pendidikan yang menunjang kemampuan berpikir kreatif dan inovatif. Hal ini penting supaya generasi penerus mempersiapkan diri untuk menghadapi dunia yang sudah canggih akan terknologi atau disebut juga dengan era 4.0.

Untuk menghadapi era 4.0 mungkin telah banyak dilakukan di bidang pendidikan seperti penemuan karya-karya inovatif berupa model pembelajaran, media pembelajaran, strategi pembelajaran, dan metode pembelajaran. Untuk menunjang karya tulis ini sesuai dengan penelitian yang dilakukan oleh (Satriawan \& Rosmiati, 2016), bahan ajar yang baik dapat mendukung kegiatan pembelajaran secara efektif dan efisien sehingga tujuan pembelajaran akan lebih mudah tercapai. Dengan adanya materi ajar yang baik, peserta didik juga dapat mendiskusikan materi ajar tersebut sebelum pembelajaran di kelas dimulai, sehingga mereka lebih mudah mengetahui kompetensi apa yang akan mereka capai di pembelajaran tersebut.

Dari hasil analisis angket di salah satu sekolah didapatkan informasi bahwa peserta didik beranggapan bahwa fisika adalah salah satu pembelajaran yang kurang diminati karena banyak rumus-rumus yang ada dalam pembelajaran fisika. Oleh sebab itu, peserta didik dalam memahami konsep fisika kurang baik

Berdasarkan wawancara langsung dengan beberapa peserta didik, diperoleh informasi bahwa fisika sulit dipahami dikarenakan tidak memiliki pegangan atau bahan bacaan yang menarik. Pendidik hanya memanfaatkan sumber belajar yang ada di sekolah seperti buku paket serta lembar kerja siswa. Oleh sebab itu, banyak peserta didik yang kurang bisa memahami bahasa dalam buku sumber yang ada tersebut. Berdasarkan masalah di atas, maka dibutuhkan bahan ajar yang bisa menunjang peserta didik untuk belajar.

Agar peserta didik dapat memahami dengan baik dan mengulang materi, dibutuhkan bahan ajar yang menarik. Bahan ajar yang bisa digunakan dalam aktivitas belajar yaitu modul Menurut (Basri, 2015) "modul adalah alat atau sarana pembelajaran yang berisi materi, metode, batasan materi pembelajaran, petunjuk kegiatan belajar, latihan dan cara mengevaluasi yang dirancang secara sistematis untuk mencapai kompetensi yang diharapkan dan dapat digunakan secara mandiri". Jadi, modul tidak hanya berisi langkahlangkah kerja saja tetapi juga berisi evaluasi untuk mencapai kompetensi.

Dalam aktivitas belajar, agar suasana belajar tidak monoton juga diperlukan sebuah model pembelajaran. Tidak sedikit model pembelajaran yang diterapkan pendidik saat aktivitas belajar. Model pembelajaran ini dipilih oleh pendidik berdasarkan materi pelajaran dan disesuaikan dengan kurikulum yang berlaku. Satu diantaranya model pembelajaran yang disarankan untuk kurikulum 2013 yaitu model pembelajaran inquiry.

Pembelajaran dengan model inquiry ini berpusat pada peserta didik sehingga peserta didik benarbenar terlibat secara aktif dalam proses pembelajaran. (Buyung, 2017) mengatakan bahwa model pembelajaran inquiry berupaya menanamkan dasar-dasar berpikir ilmiah pada 
diri peserta didik, sehingga dalam proses pembelajaran peserta didik ini lebih banyak belajar sendiri, mengembangkan kreativitas dalam bernalar.

Pembelajaran berorienetasi inquiry menunjang peserta didik untuk mengembangkan keterampilan menyelesaikan persoalan. Keterampilan menyelesaikan persoalan yaitu kecakapan yang diperlukan oleh peserta didik terutama saat menghadapi pesatnya arus globalisasi serta informasi dewasa ini. Tahapan model pembelajaran inquiry seperti pada Tabel 1

Tabel 1. Tahapan Model Pembelajatan Inquiry

\begin{tabular}{|c|c|}
\hline Tahap & Kegiatan Guru \\
\hline Orientasi & $\begin{array}{l}\text { Guru memberikan suatu } \\
\text { persoalan yang } \\
\text { berhubungan dengan } \\
\text { materi yang dipelajari }\end{array}$ \\
\hline $\begin{array}{l}\text { Merumuskan } \\
\text { Masalah }\end{array}$ & $\begin{array}{lr}\text { Guru meminta peserta } \\
\text { didik } & \text { mengajukan } \\
\text { pertanyaan berdasarkan } \\
\text { persoalan yang diberikan. }\end{array}$ \\
\hline $\begin{array}{l}\text { Merumuskan } \\
\text { Hipotesis }\end{array}$ & $\begin{array}{lr}\text { Guru memberikan } \\
\text { kesempatan pada peserta } \\
\text { didik } \\
\text { mengemukakan } \\
\text { pendapatnya } \\
\text { persoalan yang diberikan. }\end{array}$ \\
\hline $\begin{array}{l}\text { Mengumpulkan } \\
\text { Data }\end{array}$ & $\begin{array}{l}\text { Guru memberikan materi } \\
\text { untuk membimbing } \\
\text { peserta didik menemukan } \\
\text { konsep yang sedang } \\
\text { dipelajari. }\end{array}$ \\
\hline Menguji Hipotesis & $\begin{array}{l}\text { Guru memberikan latihan } \\
\text { untuk meningkatkan } \\
\text { pemahaman peserta didik }\end{array}$ \\
\hline
\end{tabular}

(Hosnan, 2016)

Pada penelitian ini materi yang digunakan dalam pengembangan modul yaitu pada materi elastisitas serta hukum hooke. Materi elastisitas serta hukum hooke dipilih karena materi ini terdapat beberapa contoh yang bisa diamati untuk kehidupan. Penelitian ini bertujuan untuk menghasilkan modul fisika berorientasi model pembelajaran inquiry yang valid dan praktis untuk peserta didik.

\section{METODE PENELITIAN}

Penelitian dilaksanakan di kelas XI MIA SMAN 1 Pantai Cermin pada materi elastisitas dan hukum hooke. Jenis penelitian ini adalah penelitian Research and Development (R\&D). (Sugiyono, 2011) "penelitian dan pengembangan (R\&D) adalah metode penelitian yang digunakan untuk menghasilkan produk yang valid dan praktis. Penelitian pengembangan ini bertujuan untuk menghasilkan sebuah produk dalam bidang pendidikan, yaitu berupa modul.

Model 4-D (four-D models) digunakan untuk mengembangkan modul fisika berorientasi inquiry (Trianto, 2011). Model ini terdiri dari 4 tahap pengembangan, yaitu define, (pendefenisian), design (perancangan), develop (pengembangan), dan disseminate (penyebaran).

Kelayakan produk ini dinilai dari validitas dan praktikalitas produk. Validitas berasal dari kata validity artinya sejauh mana ketepatan dan kecermatan instrumen pengukur dalam melakukan fungsinya (Ridho, 2020). Sedangkan praktikalitas adalah tingkat kemudahan yang dialami pendidik dalam membelajarkan peserta didik dengan menggunakan suatu produk atau bahan ajar.

Analisis validitas dilaksanakan menggunakan skala likert dengan ketentuan: sangat setuju $=4$, setuju $=3$, tidak setuju $=2$, sangat tidak setuju $=$ 1. Perhitungan nilai akhir yang dinyatakan dalam skala (0-100) dihitung menggunakan persamaan 1. Kategori validitas modul pembelajaran berbasis inquiry yang didasarkan pada nilai akhir serta bisa diamati pada tabel 2

$$
p=\frac{f}{n} \times 100 \%
$$


Keterangan:

$p=$ nilai validitas

$f=$ skor yang diperoleh

$n=$ skor maksimum

Tabel 2. Kategori Validitas Modul Berorientasi

\begin{tabular}{cc} 
Inquiry & \\
\hline Rentang & Kategori \\
\hline$(0-20)$ & Sangat tidak valid \\
\hline$(21-40)$ & Tidak valid \\
\hline$(41-60)$ & Kurang valid \\
\hline$(61-80)$ & Valid \\
\hline$(81-100)$ & Sangat valid \\
\hline
\end{tabular}

(Riduwan, 2009)

Quisioner respon peserta didik serta quisioner respon pendidik berhubungan dengan kepraktisan modul pembelajaran berbasis inquiry yang sudah dibuat. Analisis praktikalitas dilaksanakan menggunakan skala likert dengan ketentuan: sangat setuju $=4$, setuju $=3$, tidak setuju $=2$, sangat tidak setuju $=1$. Perhitungan nilai akhir yang dinyatakan dalam skala (0-100) dihitung menggunakan persamaan 2 dan diinterpretasikan berdasarkan informasi dalam Tabel 3.

$$
p=\frac{f}{n} \times 100 \%
$$

Keterangan:

$p=$ nilai praktikalitas

$f=$ skor yang diperoleh

$n=$ skor maksimum

Tabel 3. Kategori Kepraktisan Modul Berorientasi Inquiry

\begin{tabular}{cc}
\hline Rentang & Kategori \\
\hline$(0-20)$ & Sangat tidak praktis \\
\hline$(21-40)$ & Tidak praktis \\
\hline$(41-60)$ & Kurang praktis \\
\hline$(61-80)$ & Praktis \\
\hline$(81-100)$ & Sangat praktis \\
\hline
\end{tabular}

(Riduwan ,2009)

\section{HASIL DAN PEMBAHASAN}

Prosedur penelitian modul fisika berorientasi model pembelajaran inquiry untuk peserta didik menggunakan model 4-D sebagai berikut:

\section{Tahap Define (Pendefinisian)}

Tahap ini dilaksanakan untuk melihat permasalahan awal belajar peserta didik di kelas XI MIA 2 SMAN 1 Pantai Cermin yang berhubungan dengan proses pembelajaran peserta didik. Hasil tahapan ini adalah berupa: a) analisis kurikulum yaitu materi elastisitas dan hukum hooke sudah sesuai dan terkait dengan KI dan KD yang telah ditetapkan, b) analisis konsep yang bertujuan untuk mengidentifikasi, merinci, serta merumuskan konsep utama pada materi elastisitas serta hukum hooke. Selanjutnya c) analisis peserta didik bertujuan untuk melihat karakter masing-masing peserta didik. Analisis peserta didik dilaksanakan dengan membagikan kuisioner analisis awal kepada pendidik serta peserta didik.

Berdasarkan angket analisis awal yang sudah diberikan diperoleh informasi bahwa kemampuan peserta didik dalam menguasai konsep fisika masih lemah. Hal ini dikarenakan peserta didik tidak memahami dengan baik materi fisika. Oleh karena itu, diberikan alternatif untuk memudahkan peserta didik dalam belajar yaitu dengan menggunakan modul fisika berorientasi inquiry.

\section{Tahap Design (Perancangan)}

Pada tahap ini tindakan yang dilaksanakan adalah mendesain modul fisika berorientasi model pembelajaran inquiry. Modul yang dirancang memiliki format sebagai berikut: a) cover pada modul fisika berorientasi model pembelajaran inquiry terdiri dari judul, sampul dirancang dengan kombinasi warna biru, putih, dan orange dilengkapi dengan gambar beberapa contoh 
benda bersifat elastis dan plastis. Adapun tampilan pada cover bisa diamati di Gambar 1 .

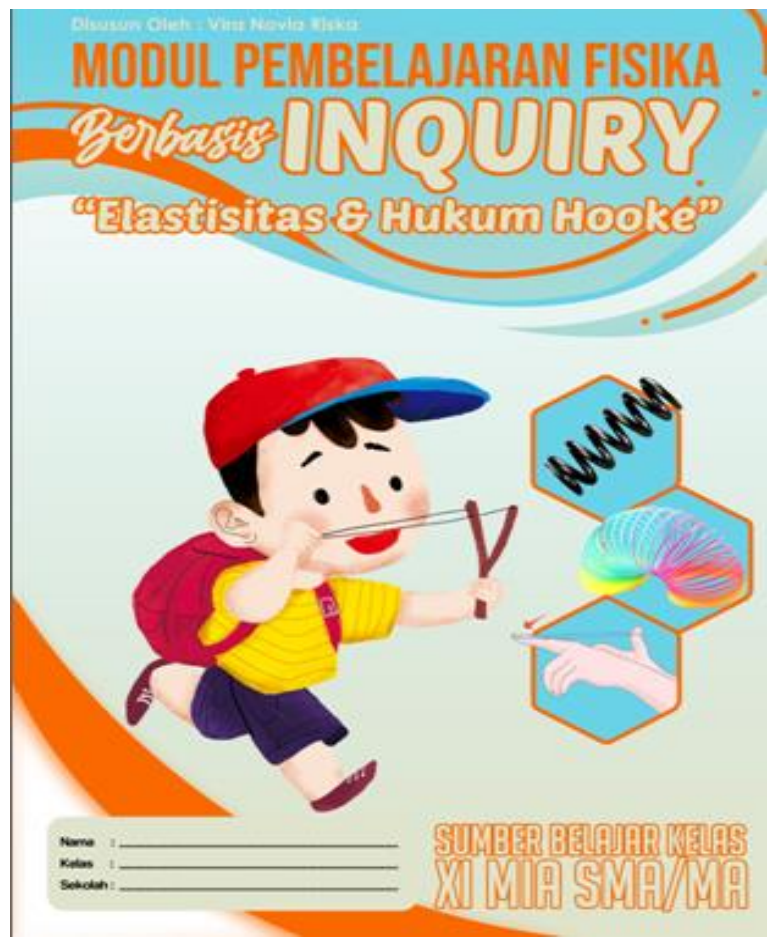

Gambar 1. Cover

Selanjutnya b) kata pengantar terdapat uraian rasa syukur penulis serta harapan penulis untuk dapat menyelesaikan modul fisika berorientasi model pembelajaran inquiry pada materi elastisitas serta hukum hooke. Kata pengantar juga berisi uraian singkat tentang isi modul dan langkah-langkah yang harus diikuti peserta didik dalam mempelajari modul., c) daftar isi ini berfungsi untuk memudahkan peserta didik saat mencari materi sesuai dengan halaman yang sudah di cantumkan, d) petunjuk penggunaan modul adalah hal yang harus diperhatikan peserta didik dan pendidik sebelum memakai modul. Bagian selanjutnya e) standar isi pada modul ini terdiri dari kompetensi inti, kompetensi dasar, indikator pencapaian kompetensi, serta tujuan belajar, f) materi pelajaran pada materi pelajaran ini terdiri dari empat tahap yang sesuai dengan model pembelajaran inquiry.

Adapun tahapanya sebagai berikut: (1) tahap orientasi disajikan sebuah permasalahan, dimana permasalahan yang disajikan berkaitan dengan kehidupan sehari-hari yang bertujuan untuk menunjang peserta didik menemukan konsep materi yang dipelajarinya, (2) tahap merumuskan masalah dan merumuskan hipotesis yakni meminta peserta didik untuk bertanya dan mengemukan pendapatnya terhadap permasalahan yang di berikan pada tahap orientasi. (3) tahap mengumpulkan data adalah disajikan materi beserta contoh soal yang berfungsi untuk bisa membantu peserta didik membuktikan apakah konsep yang ditemukan sendiri sudah merujuk pada tujuan belajar yang akan diwujudkan peserta didik, (4) serta tahap menguji hipotesis adalah memberikan latihan berupa soal, dimana dengan diberikan latihan tersebut peserta didik akan bisa memotivasi pemahaman peserta didik saat mencerna materi yang dipelajari. Adapun tampilannya seperti Gambar 2.

Selanjutnya g) daftar pustaka ini merupakan sumber materi yang di ambil dari beberapa buku, yang berfungsi untuk menyempurnakan materi untuk bisa memotivasi peserta didik dalam mencerna konsep materi yang dipelajari serta h) glosarium adalah beberapa istilah penting yang terdapat pada pada modul yang sesuai dengan materi elastisitas serta hukum hooke. 


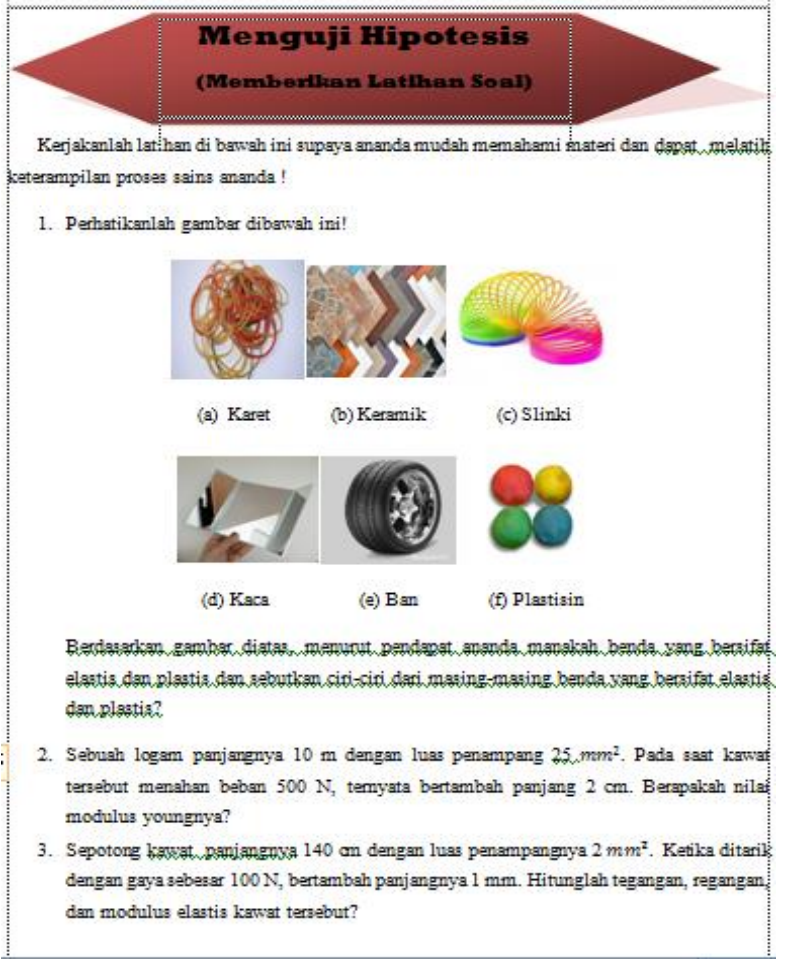

Gambar 2. Menguji Hipotesis

\section{Tahap Develop (Pengembangan)}

Tahap develop (pengembangan) di penelitian ini meliputi validasi modul dan praktikalitas modul.

\section{a. Validasi Modul}

Pada penelitian ini modul yang sudah dibuat divalidasi terlebih dahulu oleh tiga orang validator yang berasal dari pakar di bidang fisika. Validator memvalidasi modul fisika berorientasi model pembelajaran inquiry sesuai dengan lembar validasi yang diberikan, yang terdiri dari empat aspek yakni: 1) aspek kelayakan isi, 2) aspek kelayakan bahasa dan gambar, 3) aspek kelayakan penyajian, 4) aspek kelayakan kegrafikan.

Selain itu validator tidak hanya memvalidasi modul sesuai kategori yang sudah ditentukan tetapi juga memberikan komentar dan saransaran yang membangun. Berikut beberapa saran yang diberikan oleh validator bisa diamati di Tabel 5.

Tabel 5. Saran-saran Validator terhadap modul yang Dikembangkan

\begin{tabular}{cl}
\hline Validator & \multicolumn{1}{c}{ Saran-saran Validator } \\
\hline AR & $\begin{array}{l}\text { Mengganti soal yang terdapat pada } \\
\text { contoh soal modul pertemuan kedua }\end{array}$ \\
\hline HD & $\begin{array}{l}\text { Tambahkan penomoran untuk setiap } \\
\text { gambar yang disajikan pada modul }\end{array}$ \\
\hline HN & $\begin{array}{l}\text { Perbaiki kata-kata yang tertinggal } \\
\text { pada saat merancang modul }\end{array}$ \\
\hline
\end{tabular}

Saran validator ditindaklanjuti dengan merevisi modul fisika berorientasi model pembelajaran inquiry. Selanjutnya dilakukan analisis skor validitas dari masing-masing validator. Dari hasil analisis data diperoleh nilai validitas modul secara umum seperti pada Tabel 6 .

Tabel 6. Hasil Angket Validasi

\begin{tabular}{lccccc}
\hline \multirow{2}{*}{ Aspek Penilaian } & \multicolumn{3}{c}{ Validasi Ahli } & \multirow{2}{*}{$\begin{array}{c}\text { Nilai } \\
\text { Validasi (\%) }\end{array}$} & \multirow{2}{*}{ Kategori } \\
\cline { 2 - 4 } & AD (\%) & HD (\%) & HN(\%) & & \\
\hline Kelayakan isi & 84,61 & 90,38 & 75 & 83,33 & Sangat Valid \\
\hline Bahasa \& gambar & 83,33 & 86,11 & 75 & 81,48 & Sangat Valid \\
\hline Penyajian & 90 & 87,5 & 80 & 85,83 & Sangat Valid \\
\hline Kegrafikan & 95 & 85 & 75 & 85 & Sangat Valid \\
\hline \multicolumn{7}{r}{} & \multicolumn{2}{c}{ Rata-rata } & & $\mathbf{8 3 , 9 1 \%}$ & Sangat Valid \\
\hline
\end{tabular}

Berdasar tabel 6 di atas dapat disimpulkan bahwa keseluruhan aspek terkategori sangat valid. Dari keempat aspek yakni aspek kelayakan isi, aspek bahasa dan gambar, aspek penyajian serta aspek kegrafikan, Dimana keseluruhan aspek tersebut terkategori sangat valid dengan rata-rata $83,91 \%$ 
(Hayati \& Lailatussaadah, 2016). Semakin tinggi nilai validitas suatu produk, maka akan semakin jitu data yang didapatkan dari suatu penelitian. Apabila nilai validitas modul tinggi, maka instrumen tersebut dapat dipercaya dan sah. (Yusup, 2018) "semakin tinggi nilai koefisien validitas suatu produk". Oleh karena itu, secara umum modul fisika berorientasi model pembelajaran inquiry yang telah dikembangkan dinyatakan sangat valid. Hal ini bisa diartikan bahwa modul pembelajaran fisika berorientasi inquiry yang dikembangkan bisa diuji coba kepada peserta didik untuk aktivitas belajar.

\section{b. Praktikalitas Modul}

Modul fisika berorientasi model pembelajaran inquiry yang sudah dinyatakan layak uji coba oleh validator, maka modul diterapkan pada proses pembelajaran untuk mengetahui praktikalitas modul. Nilai praktikalitas modul dapat diketahui berdasarkan instrumen praktikalitas yang diisi oleh pendidik dan peserta didik. Hasil praktikalitas yang diperoleh secara umum seperti pada Tabel 7.

Tabel 7. Hasil Quisioner Praktikalitas Oleh Pendidik dan Peserta Didik

\begin{tabular}{|c|c|c|c|c|}
\hline Pengguna & Skor Total & Skor Max & Rata-rata & Kategori \\
\hline Praktikalitas Pendidik & 74 & 75 & $98,67 \%$ & Sangat Praktis \\
\hline Praktikalitas Peserta Didik & 1.698 & 70 & $86,63 \%$ & Sangat Praktis \\
\hline \multicolumn{3}{|c|}{ Total } & $92,65 \%$ & Sangat Praktis \\
\hline
\end{tabular}

Dari tabel 7 di atas bisa dirinci perolehan hasil praktikalitas modul pembelajaran fisika berorientasi inquiry dari pendidik fisika SMAN 1 Pantai Cermin secara keseluruhan adalah 92,65\% terkategori sangat praktis. (Menrisal, 2019) "semakin tinggi nilai praktikalitas suatu produk maka produk tersebut semakin layak untuk digunakan. (Anaperta, 2015) "praktisnya sebuah modul dapat diketahui dari angket yang sudah diberikan kepada pendidik dan peserta didik". Modul dikatakan sangat praktis karena memiliki aspek kemudahan penggunaan, waktu yang digunakan, mudah di interpretasikan serta memiliki ekivalensi sama.

\section{KESIMPULAN}

Berdasarkan hasil dan pembahasan diperoleh kesimpulan bahwa modul fisika berorientasi model pembelajaran inquiry untuk peserta didik dinyatakan sangat valid dengan persentase $83,91 \%$ dan sangat praktis dengan persentase $92,65 \%$. Modul ini dapat digunakan untuk proses belajar mengajar.

\section{DAFTAR PUSTAKA}

Anaperta, M. (2015). Praktikalitas Modul Fisika SMA Berbasis Model Pembelajaran Generatif Pada Materi Listrik Dinamis Terintegrasi Kelistrikan Jantung. Jurnal Riset Fisika Edukasi Dan Sains, 2(1), 2332.

Basri, H. (2015). Paradigma Baru Sistem Pembelajaran. Bandung: CV Pustaka Setia.

Buyung, B., \& Dijanto D. (2017). Analisis Kemampuan Literasi Matematis Melalui Pembelajaran Inquiry Dengan Strategi Scaffolding. Unnes Journal of Mathematics Education Research, 6(1), 112-119.

Hayati, S., \& Lailatussaadah, L. (2016). Validitas Dan Reliabilitas Instrumen Pengetahuan Pembelajaran Aktif, Kreatif Dan Menyenangkan (Pakem) Menggunaan Model Rasch. Jurnal Ilmiah Didaktika, 16(2), 169. 
Hosnan, M. (2016). Pendekatan Saintifik Dan Kontekstual Dalam Pembelajaran Abad 21. Bogor: Ghalia Indonesia.

Kunandar. (2015). Penilaian Autentik (Penilaian Hasil Belajar Peserta Didik Berdasarkan Kurikulum 2013). Jakarta: PT Raja Grafindo Persada.

Menrisal, Yunus, Y., \& Rahmadini, N. S. (2019). Perancangan Dan Pembuatan Modul Pembelajaran Elektronik Berbasis Project Based Learning Mata Pelajaran Simulasi Digital SMKN 8 Padang. Jurnal Koulutus: jurnal Pendidikan Kahuripan, 2(1), 1-16.

Parmin. (2012). Pengembangan Modul Mata Kuliah Strategi Belajar Mengajar IPA Berbasis Hasil Penelitian Pembelajaran. Jurnal Pendidikan IPA Indonesia, 1(1), 815.

Ridho, M. S. (2020). Validitas Bahan Ajar Gerak Melingkar Berbasis Authentic Learning di Lingkungan Lahan Basah Untuk Melatih Keterampilan Pemecahan Masalah. Journal of Teaching and Learning Physics, 5(2), 87-98.

Riduwan, M.B.A. (2009). Belajar Mudah Penelitian. Bandung: Anggota Ikatan Penerbit Indonesia (IKAPI).

Satriawan, K., \& Rosmiati, R. (2016). Pengembangan Bahan Ajar Fisika Berbasis Kontekstual dengan Mengintegrasikan Kearifan Lokal Untuk Meningkatkan Pemahaman Konsep Fisika Pada Mahasiswa. Jurnal Penelitian Pendidikan Sains, 6(1), 22-26.

Sugiyono. (2011). Metode Penelitian Kuantitatif Kualitatif Dan R\&D. Bandung: Alfabeta.

Trianto. (2011). Mendesain Model Pembelajaran Inovatif Progresif. Jakarta: Kencana Prenada Media Group.

Yusup. (2018). Uji Validitas Dan Reliabilitas Instrumen Penelitian Kuantitatif. Jurnal Ilmiah Kependidikan, 7(1), 17-23. 